\title{
Tail mass in a mouse
}

\author{
Charles Tyler Long, DVM ${ }^{1}$ \& Richard Luong, BVSc, DACVP 2
}

An approximately 20-month-old, 32-gram, white, ICR CD-1 female mouse was presented to the Stanford University Veterinary Service Center after the animal caretaker noted fresh blood around the bottom of the cage. The mouse was singly housed in a microisolater mouse cage with a light:dark cycle of $12 \mathrm{~h}: 12 \mathrm{~h}$ and temperature of $70 \mathrm{o} \pm 2 \mathrm{oF}$. Upon clinical examination, the mouse was in good overall body condition and well hydrated. A mass was noted on the ventral aspect of the base of the tail. The mouse was previously used for breeding purposes, and there was no history of recent tail vein blood collection. No other abnormalities were noted on clinical examination.

The mouse was humanely euthanized with carbon dioxide asphyxiation and secondary cervical dislocation. Blood was collected immediately after euthanasia via cardiopuncture for hematology and serum biochemistry analysis (Table 1). We noted a normocytic-normochromic anemia and thrombocytopenia. A necropsy was subsequently carried out, which confirmed the presence of a $1.5-\mathrm{cm} \times 1.5-\mathrm{cm} \times 1.2-\mathrm{cm}$, raised, circumscribed, dark red, soft-to-firm, multifocal, ulcerated, subcutaneous nodular mass on the ventral aspect of the base of the tail, ventral to the caudal vertebrae. No other gross lesions were observed in any other organs or tissues. All organs and tissues, including longitudinal and transverse sections of the subcutaneous tail mass, were preserved in 10\% neutralbuffered formalin or 10\% neutral-buffered formalin with formic acid (for tissues with bone). The tissues were then embedded in paraffin and routinely processed for light microscopic analysis of sections stained with hematoxylin and eosin. The tail was

\begin{tabular}{|c|c|c|}
\hline $\begin{array}{l}\text { Hematology or serum } \\
\text { biochemistry parameter }\end{array}$ & Value & $\begin{array}{l}\text { In-house } \\
\text { reference range }\end{array}$ \\
\hline White blood cells $\left(10^{3} / \mu \mathrm{l}\right)$ & 6.72 & $5.5-9.3$ \\
\hline Red blood cells $\left(10^{6} / \mu \mathrm{l}\right)$ & $3.17^{*}$ & $7.0-8.8$ \\
\hline Hemoglobin (g/dl) & $5.36^{*}$ & $13.7-16.4$ \\
\hline Hematocrit (\%) & $17.3^{*}$ & $39.0-47.0$ \\
\hline Mean corpuscular volume (fl) & 54.6 & $52.0-68.7$ \\
\hline Mean corpuscular hemoglobin (pg) & $16.9 *$ & $18.4-19.6$ \\
\hline $\begin{array}{l}\text { Mean corpuscular } \\
\text { hemoglobin concentration }(\mathrm{g} / \mathrm{dl})\end{array}$ & $31.0^{*}$ & $34.0-36.0$ \\
\hline Neutrophils $\left(10^{3} / \mu \mathrm{l}\right)$ & 403 & $825-2,604$ \\
\hline Lymphocytes $\left(10^{3} / \mu \mathrm{l}\right)$ & 6,115 & $3,685-7,812$ \\
\hline Monocytes $\left(10^{3} / \mu \mathrm{l}\right)$ & 202 & $0-279$ \\
\hline Neutrophils (\%) & 6 & $15-32$ \\
\hline Lymphocytes (\%) & 91 & $65-83$ \\
\hline Monocytes (\%) & 3 & $0-3$ \\
\hline Platelet estimate & Decreased & Adequate \\
\hline Red blood cell morphology & $\begin{array}{l}\text { Moderate anisocytosis } \\
\text { and polychromasia }\end{array}$ & - \\
\hline Glucose (mg/dl) & 183 & $184-220$ \\
\hline Alanine aminotransferase (IU/l) & 68 & $192-388$ \\
\hline Aspartate aminotransferase (IU/l) & 29 & $76-160$ \\
\hline Alkaline phosphatase (IU/l) & 55 & $171-183$ \\
\hline Total bilirubin (mg/dl) & 0 & $0.15-0.85$ \\
\hline Cholesterol (mg/dl) & 80 & $52.1-92.1$ \\
\hline Blood urea nitrogen (mg/dl) & 18 & $20.3-24.7$ \\
\hline Creatinine (mg/dl) & 0.3 & $0.1-1.1$ \\
\hline Calcium (mg/dl) & 9.5 & $8.9-9.7$ \\
\hline Total protein $(\mathrm{mg} / \mathrm{dl})$ & 4.9 & $5.0-6.2$ \\
\hline Albumin (mg/dl) & 2.6 & $3.2-3.6$ \\
\hline CPK (IU/L) & 85 & $50-300$ \\
\hline Phosphorous (mg/dl) & 8.9 & $6.15-9.85$ \\
\hline
\end{tabular}

*Value is low compared with the normal range.

comprised largely of irregularly shaped and variably sized, blood-filled vascular spaces. Histological sections of all other tissues and organs (including but not limited to liver, spleen, brain, heart, lungs, lymph nodes and bone marrow) were examined and appeared normal.
What are your differential diagnoses? Do you think the mass is traumatic, infectious or neoplastic? How do you explain the anemia?

\section{What's your diagnosis?}

${ }^{1}$ Department of Comparative Medicine and ${ }^{2}$ Veterinary Service Center, Stanford University, Stanford, CA. Correspondence should be addressed to C.T.L. (ctlong@cmexchange.stanford.edu). 